on as they would have. He has floated the Blue Nile and sailed to Greenland to climb. He has trekked to the fabled land of Hunza and climbed on Sepu Kangri, Tibet's "secret mountain." Somehow he has also managed to maintain a viable marriage and raise 2 sons.

Curran, despite being a friend and climbing companion of Bonington, has produced a balanced volume. He portrays Bonington not as an invincible superhero, but rather as a human being, fraught with insecurities and legendary indecisiveness, but driven by an unrelenting love of remote and mountainous places and a desire to stand atop unclimbed summits and to try the harder route on peaks that have already been climbed.

This is the first work I have read of the many Bonington biographies and autobiographies that exist, but surely not the last. It kept me spellbound in admiration for a man who has done what many only dream of. Recently, I checked Bonington's Web site (www.bonington.com). At 66 years old, he has just accomplished first ascents on the rocky crags of Morocco (March 2001) and has several expeditions to remote areas planned for the next couple of years - truly a life well lived and still living well. Viva Chris Bonington!

Rob Hamilton, MD

Palo Alto, CA, USA

\section{We Die Alone: A WWII Epic of Escape and Endurance}

David Howarth

New York, NY: Lyons Press, 1999

(Originally Published by The Macmillan Company, 1955)

US \$14.95, 231 pages, softcover

March 29, 1943; occupied Norway. It was a small mission in a large war: infiltrate a 4-man team of expatriate Norwegian commandos and their equipment into Norway. They had spent 6 days at sea in a small fishing boat, carefully making their way from the Shetland Islands to the far north coast of Norway. In sight of their homeland for the first time in years, the mission went terribly wrong. The commandos and the boat crew were betrayed to the occupying German forces, and in a short but vicious firefight, 1 commando was killed and 2 others plus the 8-man boat crew were captured. The German occupying forces tortured 2 of the men to death and stood the others in front of a firing squad. The fourth commando, a former instrument maker from Oslo named Jan Baalsrud, evaded capture, and on June 1, 1943, escaped from occupied Norway into Sweden.
First published in 1955, this new edition of We Die Alone features an introduction by historian Steven E. Ambrose. It is the remarkable story of the escape of Jan Baalsrud, an epic of endurance and heroism. If this were a work of fiction, it would be considered outlandish. However, 10 years after the incident, historian David Howarth carefully reconstructed and verified the story, interviewing not only Baalsrud himself, but many of the Norwegians who aided in his escape. In simple, but elegant language, without histrionics, he portrays the stark realities of a failed unconventional warfare mission: sudden unexpected firefight, prisoners of war executed, local civilian resistance workers deported to death camps, and a headlong flight into the cold of the far north spring. Yet, this is much more than a war story. It is the story of an ordinary man placed into an extraordinary situation, and the many other ordinary people who when called on rose to the occasion and risked their lives to save a single man.

Much of the time, the environment was as much the enemy as the Germans. Avalanches, storms, cold, and darkness should have killed Baalsrud several times over, yet he survived. I must confess to having to suppress shudders when at one point a Norwegian farm family treats the badly frostbitten and probably hypothermic Baalsrud by rubbing his feet with snow. Crippled, Baalsrud became entirely dependent on the courage and selfsacrifice of the inhabitants of several remote villages. At one point, he was hidden in a snow trench for several weeks, crippled and unable to move. Villagers had to climb several miles up the walls of a fjord to bring him supplies every few days, usually at night to avoid detection by the Germans.

The full story of Baalsrud's escape I will leave for readers to discover. I will say that it is a measure of the quiet heroism of Jan Baalsrud that the end of the war found him once again in occupied Norway, on another mission behind enemy lines, fighting to free his country from occupation.

We Die Alone is a book that simply but elegantly tells of a small incident that took place in an almost forgotten theater of a huge war. It is a story of cruelty, courage, humanity, and almost unbelievable endurance. More importantly, it is the story of a man surviving the worst elements that his fellow man could throw at him and yet he prevailed. It is a story of quiet heroism that is more gripping than a dozen technothrillers. Don't start reading this book unless you have time to finish it.

Robert C. Allen, DO San Antonio, TX, USA 